\title{
THE
}

2014

\section{Tree Responses to an Invasive Sap-Feeding Insect}

Liahna Gonda-King

Sara Gomez

Jessica L. Martin

Colin M. Orians

Evan L. Preisser

University of Rhode Island, preisser@uri.edu

Follow this and additional works at: https://digitalcommons.uri.edu/bio_facpubs

The University of Rhode Island Faculty have made this article openly available.

Please let us know how Open Access to this research benefits you.

This is a pre-publication author manuscript of the final, published article.

Terms of Use

This article is made available under the terms and conditions applicable towards Open Access

Policy Articles, as set forth in our Terms of Use.

\section{Citation/Publisher Attribution}

Gonda-King, L., Gomez, S., Martin, J. L., Orians, C. M., \& Preisser, E. L. (2014). Tree responses to an invasive sap-feeding insect. Plant Ecology, 215(3), 297-304. http://dx.doi.org/10.1007/s11258-014-0298-y 


\section{Tree responses to an invasive sap-feeding insect} and Evan L. Preisser ${ }^{\mathrm{a}}$ 


\section{Abstract}

15 Although sap-feeding insects are known to negatively affect plant growth and physiology, less is

16 known about sap-feeding insects on woody plants. Adelges tsugae (Annand Hemiptera:

17 Adelgidae), the hemlock woolly adelgid, is an invasive sap-feeding insect in eastern North

18 America that feeds on and kills Tsuga canadensis (L. Carrière), eastern hemlock. In the summer,

19 newly hatched nymphs crawl to young unattacked tissue, settle and immediately enter diapause

20 (aestivation) while attached to hemlock. We assessed the effect of A. tsugae infestation on $T$.

21 canadensis growth and physiology by analyzing hemlock growth, water potential,

22 photosynthesis, stomatal conductance, and foliar nitrogen $(\% \mathrm{~N})$. A. tsugae infestation decreased

23 eastern hemlock growth, and photosynthesis. Additionally, adelgid-infested hemlocks exhibited

24 signs of water stress that included reductions in water potential and stomatal conductance. These

25 responses shed light on possible mechanisms of adelgid-induced mortality.

27 Key-words: Tsuga canadensis, water potential, gas exchange, \% nitrogen, plant-insect

28 interactions 


\section{Introduction}

31 Sap-feeders often have long-lasting physiological impacts on their host plant. These

32 physiological changes are driven by both changes in plant nutrients (Masters \& Brown 1992;

33 McClure 1980) and the production of secondary chemicals (Haukioja et al. 1990; Karban \&

34 Myers 1989). By removing nutrients from the plants' xylem or phloem, sap-feeding insect

35 herbivores decrease plant growth, photosynthesis rates, and reproduction (Candolfi et al. 1993;

36 Meyer 1993). In fact, in some systems sap-feeding insects cause greater damage to woody plants

37 than do defoliators (Zvereva et al. 2010).

Relatively few studies have investigated the effects of sap-feeding herbivores on woody

39 species (reviewed in Zvereva et al. 2010). Conifers may be especially susceptible to sap-feeders

40 because they allocate more storage compounds to foliage as opposed to deciduous trees that store

41 resources in their roots, stems, and other tissues inaccessible to sap feeders (Chapin et al. 1990;

42 Hester et al. 2004; Krause \& Raffa 1996b). The lack of such stored resources may make conifers

43 more likely to succumb to intense sap-feeding events (Fernandes 1990; Furuta \& Aloo 1994;

44 Paine 2000). The invasive hemlock woolly adelgid (Adelges tsugae Annand Hemiptera:

45 Adelgidae) is a specialist sap-feeding insect currently decimating eastern hemlock (Tsuga

46 canadensis (L.) Carrière), a foundation species in eastern North American forests. Adelges

47 tsugae feed by inserting their stylet bundle at the base of a needle into the ray parenchyma tissue

48 (Young et al. 1995) and can kill mature hemlocks within four years of infestation (McClure

49 1991). Once A. tsugae selects a feeding place, it remains sessile throughout its entire life cycle.

$50 \quad$ Adelges tsugae has two generations in its invaded range; each generation passes through

51 four larval instars before becoming adults. The April - June progredien generation lays eggs that

52 hatch in July; the sistens generation that emerges remains on hemlock until the following April 
53 when the cycle starts again (McClure 1989). While the progrediens generation feeds

54 continuously throughout their shorter life cycle, the sistens generation enters diapause, a period

55 of arrested growth and metabolic depression, immediately after hatching and settling on young

56 plant tissue with no previous direct exposure to A. tsugae. Summer diapause, also known as

57 aestivation, in A. tsugae is primarily induced by temperature (Salom 2001); Lagalante et al.

58 (2006) suggest that A. tsugae enters diapause to avoid seasonal increases in plant terpenoids.

59 The aim of this study was to determine how A. tsugae impacts hemlock anatomy and

60 physiology. Specifically, we assessed hemlock growth during its growing season (April-July)

61 and quantified physiological plant responses as a proxy for host performance (water potential,

62 photosynthesis, stomatal conductance, and foliar nitrogen concentration) once the foliage had

63 fully matured. We took these measurements in September when the sistens generation is in

64 diapause and in October, immediately after A. tsugae resumed feeding (Fig. 1).

$65 \quad$ Materials and methods

Study Site: In April 2011, one-year-old T. canadensis seedlings ( $\sim 3 \mathrm{~m}$ in height) were

67 purchased from Van Pines (West Olive, MI, USA) and planted in a grid in a randomized

68 complete block design at the Kingston Wildlife Research Station (Kingston, RI). Treatments

69 were randomly assigned within each row of the grid and each row contained every treatment.

70 Trees ( $\mathrm{n}=15$ per treatment) were either experimentally inoculated with A. tsugae or remained

71 uninfested. Insect inoculations were applied in April 2011 and 2012 following a standard

72 protocol (see Butin et al. 2007). Briefly, adelgid-infested hemlock branches collected from

73 naturally-infested trees were attached to the trees in the insect treatment while control trees

74 received uninfested branches. Each sapling was enclosed in a cylindrical wire cage (0.3-m

75 diameter, 0.9-m height) covered by a mesh bag (Agribon-15, Johnny's Selected Seeds, 
Waterville, ME, USA; 90\% light transmission) to prevent cross-contamination. Prior to each

77 physiological sampling (see details below), we counted the number of $A$. $t$ sugae present $/ \mathrm{cm}$ of

78 sampled foliage in branches from A. tsugae-infested trees.

Hemlock Growth: In April, at the beginning of the plant growing season, two terminal branches and two side branches per tree $(n=15)$ were marked. For each marked branch, we

81 measured length of new growth starting at bud break (April 28, 2012) and counted the number of

82 buds (starting on June 15) on the newly produced growth (hereafter referred to as 'secondary

83 buds'). We measured growth and counted buds every two weeks thereafter until July 30, 2012

84 (when the production of new growth ceased).

Water Potential: On September 8 and October 27, 2012 we measured pre-dawn shoot water potential on 12 randomly-chosen trees per treatment in the A. tsugae-infested and control treatments. Between 4:00-5:30 am on each date, we collected one $\sim 5 \mathrm{~cm}$ cutting from a terminal

88 branch from each tree, wrapped i it ina wet paper towel, placed it in a bag and immediately

89 brought it back to the laboratory in a cooler. Each branch was placed in the pressure chamber of

90 a Scholander pressure bomb (3005 Plant Water Status Console, Soil Moisture Equipment, Santa

91 Barbara, CA, USA) and we recorded the pressure at which xylem appeared visible at the tip of

92 the branch under a magnifying glass.

93 Gas Exchange: We measured gas exchange of new growth (2012) foliage on a terminal

94 branch on each tree used to quantify water potential. Measurements were conducted between

95 9:00-11:00 am on September 9 and October 26, 2012. After each measurement, foliage inside the

96 cuvette was excised and photographed; we quantified total needle area using ImageJ 1.44

97 software (Abràmoff et al. 2004) to use in gas exchange calculations. To determine gas exchange

98 rates we used a CIRAS-2 portable photosynthesis system (PP systems, Haverhill, MA, USA) 
99 with a $2.5 \mathrm{~cm}^{2}$ cuvette and a CIRAS-2 LED light source of $1500 \mu \mathrm{molm}^{-2} \mathrm{~s}^{-1}$, a CO $\mathrm{CO}^{2}$ concentration 100 of $390 \mathrm{ppm}$, air flow rate at $350 \mathrm{~cm}^{3} \mathrm{~s}^{-1}$ and leaf temperature of $25^{\circ} \mathrm{C}$.

101 Total \% Nitrogen: We collected new growth needles and stems from 2012 growth for $A$. 102 tsugae-infested $(\mathrm{n}=15)$ and control trees $(\mathrm{n}=15)$ in September and October. These needles and 103 stems were oven dried to constant weight at $70^{\circ} \mathrm{C}$ and then finely ground. We determined total $104 \% \mathrm{~N}$ through analysing $\sim 2-3 \mathrm{mg}$ of each sample by dry combustion with a CHNOS analyzer 105 (vario Micro cube, Elementar Americas, Mt. Laurel, NJ). Statistical Analyses: All statistical analyses were performed using JMP 10.0 with each

107 data point being the mean response variable per tree per sampling date. We used repeated-

108 measures ANOVA to analyze the effect of time (repeated factor), treatment, branch type

109 (terminal or side) and all interactions on growth and bud number. We used repeated-measures 110 ANOVA to analyze the main effects of treatment and time, and the treatment*time interaction, 111 on the following variables: water potential, net photosynthesis, stomatal conductance, and \% $\mathrm{N}$. 112 We used linear regression to assess the within-treatment correlation between $A$. tsugae density 113 and water potential, photosynthesis, and stomatal conductance for both time points. We checked 114 all data for normality, homogeneity of variance and sphericity. Water potential data were log 115 transformed in order to meet ANOVA assumptions. For analyses that did not meet the 116 assumptions of sphericity, Greenhouse-Geisser corrected p-values are reported.

$117 \quad$ Results

118 Hemlock Growth: Adelges tsugae infestation had a significant effect on hemlock growth $119\left(\mathrm{~F}_{1,52}=7.16, P=0.010\right.$; Figs $2 \mathrm{~A}$ and $\left.2 \mathrm{~B}\right)$ and bud production $\left(\mathrm{F}_{1,52}=12.34, P=0.0009\right.$; Figs $2 \mathrm{C}$, 120 2D). By the end of the growing season, terminal and side branches on control trees were $41 \%$ 121 and 57\% longer, respectively, than on A. tsugae-infested trees. There was a significant 
122 time*treatment interaction $\left(\mathrm{F}_{6,312}=136.77, P=0.0078\right)$ and time*tissue type interaction

$123\left(\mathrm{~F}_{6,312}=12.67, P<0.001\right)$. However, there was no time*treatment*tissue interaction. Branch type

124 had a significant effect on growth and bud production. Terminal branches grew more

$125\left(\mathrm{~F}_{1,52}=16.49, P<0.001\right)$ and produced more secondary buds $\left(\mathrm{F}_{1,52}=23.78, P<0.001\right)$ than side

126 branches. The number of buds increased over time $\left(\mathrm{F}_{3,156}=2.52, P<0.001\right)$ and there was a

127 time*tissue interaction $\left(\mathrm{F}_{3,156}=5.22, P=0.003\right)$. There were no time*treatment or

128 time*treatment*tissue interactions.

129 Water Potential: Water potential was $45 \%$ higher in control branches than A. tsugae-

130 infested branches $\left(\mathrm{F}_{1,20}=11.36, P=0.003\right.$; Fig. 3$)$. Water potential changed over time $\left(\mathrm{F}_{1,20}=7.93\right.$,

$131 P=0.011)$, but there was no time*treatment interaction $\left(\mathrm{F}_{1,20}=0.02, P=0.900\right)$. On both dates,

132 there was a significant negative correlation between A. tsugae density and water potential

133 (September: $\mathrm{F}_{1,35}=9.55, P=0.006, \mathrm{R}_{2}=0.313$; October: $\mathrm{F}_{1,21}=7.38, P=0.010, \mathrm{R}_{2}=0.123$ ).

134 Gas Exchange: Net photosynthetic rates and stomatal conductance were lower in $A$.

135 tsugae-infested trees $\left(\mathrm{F}_{1,22}=7.70\right.$ and $14.75, P=0.011$ and $<0.001$ respectively; Figs 4A,B)

136 compared to control trees. Photosynthesis and stomatal conductance were greater in October

$137 \quad\left(\mathrm{~F}_{1,22}=37.89\right.$ and 111.04 , respectively, both $\left.P<0.001\right)$. There was a significant time*treatment

138 interaction for both gas exchange variables $\left(\mathrm{F}_{1,22}=9.43\right.$ and $11.35, P=0.006$ and 0.003 ,

139 respectively). There was a negative correlation between $A$. tsugae density and stomatal

140 conductance for both September $\left(\mathrm{F}_{1,21}=6.38, P=0.020, \mathrm{R}_{2}=0.233\right)$ and $\operatorname{October}\left(\mathrm{F}_{1,22}=7.18\right.$,

$\left.141 P=0.013, \mathrm{R}_{2}=0.238\right)$. There was no relationship between $A$. tsugae density and photosynthesis

142 for September $\left(\mathrm{F}_{1,21}=1.06, P=0.314\right)$ but was marginally significant for October $\left(\mathrm{F}_{1,22}=4.02\right.$,

$143 P=0.057)$. 
$145 \quad\left(\mathrm{~F}_{1,51}=200.87, P<0.001\right.$; Figs 5A,B $)$. Adelgid-infested foliage had higher $\% \mathrm{~N}$ concentration than

146 control trees $\left(\mathrm{F}_{1,51}=8.47, P=0.0053\right)$. Interestingly, $\% \mathrm{~N}$ was greater in infested trees in

147 September but not October (time*treatment interaction; $\mathrm{F}_{1,51}=12.59, P<0.001$ ). When A. tsugae

148 were in aestivation (September), \% N content was $13 \%$ higher in A. tsugae -infested needles and

$14927 \%$ higher in A. tsugae-infested stems. However, when A. tsugae were actively feeding in

150 October the $\% \mathrm{~N}$ content differed by less than $1 \%$ for both needles and stems compared to control

151 trees.

\section{Discussion}

153 Our study investigated the effects of an insect's presence on various plant performance

154 traits. We found that A. tsugae had significant impacts on hemlock growth. The progrediens

155 generation settles and begins to feed immediately before the start of the hemlock growing

156 season. By the end of the growing season, terminal branches on control trees were $41 \%$ longer

157 and had 56\% more new buds than A. tsugae-infested trees. The effect of A. tsugae was even

158 more pronounced on side branches. Side branches on uninfested trees grew $56 \%$ more and had

$159120 \%$ more new buds than A. tsugae-infested trees. The significant treatment*time interactions

160 for both terminal and side branches suggests that $A$. tsugae has a greater negative impact later in

161 the growing season. While other studies have shown that A. tsugae has a detrimental impact on

162 hemlock growth (McClure 1991; Miller-Pierce et al. 2010), we showed that A. tsugae-infested

163 trees have significantly less lateral growth and buds than uninfested trees. If these trends

164 continue, such difference in branch architecture could have profound effects on small insects

165 with limited active dispersal such as A. tsugae. Lateral and increased branching can promote 
166 herbivore tolerance by increasing sectored subunits within a plant and augmenting resource 167 capture (reviewed in Stowe et al. 2000).

168 The negative effect of $A$. tsugae continued even after hemlock growth ceased. Adelgid-

169 infested trees had lower photosynthetic and stomatal conductance rates; this difference was

170 evident in September but was magnified in October. In September, A. tsugae reduced

171 photosynthesis and stomatal conductance by $10 \%$ and $29 \%$, respectively, compared to control

172 trees. In October, however, photosynthesis and stomatal conductance were $36 \%$ and $41 \%$ lower

173 in infested trees. The hemlocks' magnified response to A. tsugae presence in October is likely

174 due to the fact that $A$. tsugae have broken aestivation and are actively feeding by the October

175 time point (Fig. 1). This is congruent with the idea that sap-feeding insects generally tend to

176 decrease photosynthesis (reviewed in Zvereva et al. 2010) and suggests that this occurs even

177 when a sap-feeding insect is present but inactive.

178 The impact of A. tsugae may be caused by physical injury or chemical cues associated

179 with the initial stylet insertion. Stylet insertion by other sucking insects has been shown to cause

180 long-lasting anatomical and physiological changes (Ecale \& Backus 1995; Ladd \& Rawlins

181 1965; Shackel et al. 2005). Adelges tsugae secretes a salivary sheath when feeding at the base of

182 hemlock needles that Young et al. (1995) suggests may be 'toxic' and responsible for the

183 disproportional negative impact on hemlock growth caused by A. tsugae feeding. In support of

184 the 'toxic' saliva hypothesis, Radville et al. (2011) found that A. tsugae elicits a local and

185 systemic hypersensitive response in hemlock. Alternatively, the adelgid's impact on

186 photosynthesis and stomatal conductance might be explained by long-lasting changes in nutrient

187 allocation originated when $A$. tsugae feeding. 
189 can compete with natural plant sinks (i.e. actively growing tissues). This appears to be true when

190 A. tsugae is actively feeding but not when in diapause, as indicated by a $13 \%$ decrease in $\% \mathrm{~N}$

191 after A. tsugae resumes feeding in October. During diapause, A. tsugae-infested needles and

192 stems have higher $\% \mathrm{~N}$ than control trees, but once $A$. $t$ sugae begin feeding $\% \mathrm{~N}$ does not differ

193 between A. tsugae-infested and controls. Adelges tsugae feeding is known to alter local and

194 systemic foliar nitrogen content (Gómez et al. 2012; Miller-Pierce et al. 2010; Stadler et al.

195 2005). Nitrogen sink competition between feeding herbivores and new foliage alters leaf nutrient

196 status, resulting in decreased photosynthesis (Larson 1998). Since A. tsugae feed on

197 photosynthate from xylem ray parenchyma cells (Young et al. 1995) that transfer and store

198 nutrients it is likely A. tsugae induce greater sinks when feeding than when in diapause.

199 Although the increase in $\% \mathrm{~N}$ of $A$. tsugae-infested trees might increase photosynthesis since

200 most leaf $\mathrm{N}$ is incorporated into photosynthetic enzymes and pigments (Evans 1989), we instead

201 documented consistent decreases in photosynthesis. Adelges tsugae feeding increases free amino

202 acids (Gómez et al. 2012), a finding that would explain the increase in total \% $\mathrm{N}$ found in our

203 study.

High \%N (White 1984), low photosynthetic activity and low stomatal conductance (Dang

205 et al. 1997; Epron \& Dreyer 1993; Farquhar \& Sharkey 1982) are often linked with water stress.

206 Hemlocks exhibited greater water stress (i.e., more negative water potential) both when A. tsugae

207 were in diapause and feeding. For both time points, this effect was density dependent; water

208 potential was negatively correlated with A. tsugae density. Adelgid-induced water stress may

209 result from the increased formation of false rings in A. tsugae-infested branches (Gonda-King et

210 al. 2012, Domec et al. 2013). False rings are bands of abnormal wood within an annual ring that 
211 consist of thick-walled xylem cells and which may hinder water transport efficiency (Mitchell

212 1967). If reductions in water potential are driven by false ring formation, this permanent change

213 in wood anatomy would have a long-lasting impact on water relations and may explain why $A$.

214 tsugae feeding impacts tree physiology.

215 The A. tsugae-hemlock interaction provides an ideal system to study how the presence of

216 sap-feeding insects impact host-plant physiology and performance. Overall, our results suggest

217 that A. tsugae-infested trees are water stressed as shown by decreased hemlock growth, water

218 potential, photosynthesis and stomatal conductance congruent with other hypotheses ). These

219 physiological changes in A. tsugae-infested trees may shed light on possible mechanisms behind

220 A. tsugae-induced death. We suggest taking long-term measurements on A. tsugae-infested trees,

221 from infestation to mortality, to better clarify the mechanism of A. tsugae-induced death.

\section{Acknowledgements}

224 The authors thank two anonymous reviewers for insightful comments on the manuscript. LGK

225 was supported by a URI fellowship. This project was funded by an RI-AES Hatch Grant RH-

22605262 and NIFA 2011-67013-30142 to ELP.

\section{$227 \quad$ Literature Cited}

228 Abràmoff M.D., Magalhães P.J. and Ram S.J. 2004. Image processing with ImageJ.

229 Biophotonics International 11: 36-42.

230 Andrewartha H.G. 1952. Diapause in relation to the ecology of insects. Biological Reviews 27:

$231 \quad 50-107$.

232 Archibald S. and Bond W.J. 2003. Growing tall vs growing wide: tree architecture and allometry

233 of Acacia karroo in forest, savanna, and arid environments. Oikos 102: 3-14.

234 Butin E., Preisser E. and Elkinton J. 2007. Factors affecting settlement rate of the hemlock

235 woolly adelgid, Adelges tsugae, on eastern hemlock, Tsuga canadensis. Agricultural and Forest

236 Entomology 9: 215-219.

237 Candolfi M.P., Jermini M., Carrera E. and Candolfi-Vasconcelos M.C. 1993. Grapevine leaf gas 238 exchange, plant growth, yield, fruit quality and carbohydrate reserves influenced by the grape 239 leafhopper, Empoasca vitis. Entomologia Experimentalis et Applicata 69: 289-296. 
Chapin F.S. 1990. The ecology and economics of storage in plants. Annual Review of Ecology and Systematics 21: 423-447.

242 Chapin F.S., Schulze E.D. and Mooney H.A. 1990. The ecology and enonomics of storage in plants. Annual Review of Ecology and Systematics 21: 423-447.

Dalin P. and Nylin S. 2012. Host-plant quality adaptively affects the diapause threshold: evidence from leaf beetles in willow plantations. Ecological Entomology 37: 490-499. Dang Q.-L., Margolis H.A., Coyea M.R., Sy M. and Collatz G.J. 1997. Regulation of branchlevel gas exchange of boreal trees: roles of shoot water potential and vapor pressure difference. Tree Physiology 17: 521-535.

Domec J.-C., Rivera L.N., King J.S., Peszlen I., Hain F., Smith B. and Frampton J. 2013. Hemlock woolly adelgid (Adelges tsugae) infestation affects water and carbon relations of eastern hemlock (Tsuga canadensis) and Carolina hemlock (Tsuga caroliniana). New Phytologist: 199: 452-463.

Ecale C.L. and Backus E.A. 1995. Time course of anatomical changes to stem vascular tissues of alfalfa, Medicago sativa, from probing injury by the potato leafhopper, Empoasca fabae. Canadian Journal of Botany 73: 288-298.

Epron D. and Dreyer E. 1993. Long-term effects of drought on photosynthesis of adult oak trees [Quercus petraea (Matt.) Liebl. and Quercus robur L.] in a natural stand. New Phytologist 125: 381-389.

Evans J. 1989. Photosynthesis and nitrogen relationships in leaves of C3 plants. Oecologia 78: 919.

Farquhar G.D. and Sharkey T.D. 1982. Stomatal conductance and photosynthesis. Annual review of plant physiology 33: 317-345.

Fernandes G.W. 1990. Hypersensitivity: A neglected plant-resistance mechanism against insect herbivores. Environmental Entomology 19: 1173-1182.

Furuta K. and Aloo I.K. 1994. Between-tree distance and spread of the Sakhalin fir aphid (Cinara todocola Inouye) (Homoptera: Aphididae) within a plantation. Journal of Applied Entomology 117: 64-71.

Goehring L. and Oberhauser K.S. 2002. Effects of photoperiod, temperature, and host plant age on induction of reproductive diapause and development time in Danaus plexippus. Ecological Entomology 27: 674-685.

Gómez S., Orians C. and Preisser E. 2012. Exotic herbivores on a shared native host: tissue quality after individual, simultaneous, and sequential attack. Oecologia 169: 1015-1024. Gonda-King L., Radville L. and Preisser E.L. 2012. False ring formation in eastern hemlock branches: impacts of hemlock woolly adelgid and elongate hemlock scale. Environmental Entomology 41: 523-531.

Hahn D.A. and Denlinger D.L. 2007. Meeting the energetic demands of insect diapause: Nutrient storage and utilization. Journal of Insect Physiology 53: 760-773. Hahn D.A. and Denlinger D.L. 2011. Energetics of insect diapause. Annual Review of Entomology 56: 103-121.

Haukioja E., Ruohomäki K., Senn J., Suomela J. and Walls M. 1990. Consequences of herbivory in the mountain birch (Betula pubescens ssp tortuosa): importance of the functional organization of the tree. Oecologia 82: 238-247.

Hester A.J., Millard P., Baillie G.J. and Wendler R. 2004. How does timing of browsing affect above- and below-ground growth of Betula pendula, Pinus sylvestris and Sorbus aucuparia? Oikos 105: 536-550. 
Hilker M. and Meiners T. 2006. Early herbivore alert: insect eggs induce plant defense. Journal of Chemical Ecology 32: 1379-1397. polyphagous insect herbivore. Ecology 78: 977.

Inbar M., Eshel A. and Wool D. 1995. Interspecific competition among phloem-feeding insects mediated by induced host-plant sinks. Ecology 76: 1506-1515.

Kaplan I., Sardanelli S., Rehill B.J. and Denno R.F. 2011. Toward a mechanistic understanding of competition in vascular-feeding herbivores: an empirical test of the sink competition hypothesis. Oecologia 166: 627-636.

Karban R. and Myers J.H. 1989. Induced plant responses to herbivory. Annual Review of Ecology and Systematics 20: 331-348.

Krause S. and Raffa K. 1996a. Differential growth and recovery rates following defoliation in related deciduous and evergreen trees. Trees 10: 308-316.

Krause S.C. and Raffa K.F. 1996b. Differential growth and recovery rates following defoliation in related deciduous and evergreen trees. Trees - Structure and Function 10: 308-316. Ladd T.L. and Rawlins W.A. 1965. The effects of the feeding of the potato leafhopper on photosynthesis and respiration in the potato plant. Journal of Economic Entomology 58: 623628.

Lagalante A., Lewis N., Montgomery M. and Shields K. 2006. Temporal and spatial variation of terpenoids in eastern hemlock (Tsuga canadensis) in relation to feeding by Adelges tsugae. Journal of Chemical Ecology 32: 2389-2403.

Larson K.C. 1998. The impact of two gall-forming arthropods on the photosynthetic rates of their hosts. Oecologia 115: 161-166.

Masters G.J. and Brown V.K. 1992. Plant-mediated interactions between two spatially separated insects. Functional Ecology 6: 175-179.

McClure M. 1980. Foliar nitrogen: a basis for host suitability for elongate hemlock scale Fiorinia externa (Homoptera: Diaspididae). Ecology 61: 72-79.

McClure M. 1989. Evidence of a polymorphic life cycle in the hemlock woolly adelgid Adelges tsugae (Homoptera: Adelgidae). Annals of the Entomological Society of America 82: 50-54. McClure M. 1991. Density-dependent feedback and population cycles in Adelges tsugae (Homoptera: Adelgidae) on Tsuga canadensis. Environmental Entomology 20: 258-264. Meyer G.A. 1993. A comparison of the impacts of leaf- and sap-feeding insects on growth and allocation of goldenrod. Ecology 74: 1101-1116.

Miller-Pierce M., Orwig D. and Preisser E. 2010. Effects of hemlock woolly adelgid and elongate hemlock scale on eastern hemlock growth and foliar chemistry. Environmental Entomology 39: 513-519.

Mitchell R. 1967. Translocation of dye in grand and subalpine firs infested by the balsam woolly aphid. Pacific Northwest Forest Range Experimental Station, Portland OR.

Paine T. 2000. UC scientists apply IPM techniques to new eucalyptus pests. California agriculture (Berkeley, Calif.) 54: 8.

Radville L., Chaves A. and Preisser E.L. 2011. Variation in plant defense against invasive herbivores: Evidence for a hypersensitive response in eastern hemlock (Tsuga canadensis). Journal of Chemical Ecology 37: 592-597.

Salom S.M. 2001. Evaluation of aestival diapause in hemlock woolly adelgid (Homoptera: Adelgidae). Environmental Entomology 30: 877-882. 
Shackel K.A., de la Paz Celorio-Mancera M., Ahmadi H., Greve L.C., Teuber L.R., Backus E.A. 332 and Labavitch J.M. 2005. Micro-injection of Lygus salivary gland proteins to simulate feeding 333 damage in alfalfa and cotton flowers. Archives of Insect Biochemistry and Physiology 58: 69-83. 334 Stadler B., Müller T., Orwig D. and Cobb R. 2005. Hemlock woolly adelgid in New England 335 forests: canopy impacts transforming ecosystem processes and landscapes. Ecosystems 8: 233336247.

337 Stowe K.A., Marquis R.J., Hochwender C.G. and Simms E.L. 2000. The evolutionary ecology of 338 tolerance to consumer damage. Annual Review of Ecology and Systematics 31: 565-595.

339 Takagi S. and Miyashita T. 2008. Host plant quality influences diapause induction of Byasa

340 alcinous (Lepidoptera: Papilionidae). Annals of the Entomological Society of America 101: 392341396.

342 Vesey-FitzGerald D.F. 1973. Animal impact on vegetation and plant succession in Lake

343 Manyara National Park, Tanzania. Oikos 24: 314-324.

344 White T.C.R. 1984. The abundance of invertebrate herbivores in relation to the availability of 345 nitrogen in stressed food plants. Oecologia 63: 90-105.

346 Young R., Shields K. and Berlyn G. 1995. Hemlock woolly adelgid (Homoptera: Adelgidae):

347 stylet bundle insertion and feeding sites. Annals of the Entomological Society of America 88:

$348 \quad 827-835$.

349 Zvereva E., Lanta V. and Kozlov M. 2010. Effects of sap-feeding insect herbivores on growth 350 and reproduction of woody plants: a meta-analysis of experimental studies. Oecologia 163: 949351960. 


\section{$354 \quad$ Figures}

355 Figure 1. Timing of growth and physiological measurements in relation to the life-histories of $A$.

356 tsugae and $T$. canadensis.

357 Figure 2. Average ( \pm SE) new growth length and number of new buds in hemlocks infested with

358 A. tsugae (dark gray) or uninfested (light gray) in terminal (A, C) and side branches (B, D) from

359 bud break (April) to the end of the growing season (July).

360 Figure 3. Average ( \pm SE) water potential measurements in A. tsugae-infested (dark gray) and

361 control trees (light gray). Figure 4 . Average $( \pm$ SE) photosynthesis (A) and stomatal

362 conductance (B) in control (light gray) and A. tsugae-infested plants (dark gray).

363 Figure 5. \% nitrogen in A. tsugae-infested (dark gray) and uninfested needles (light gray) (A) and 364 stems (B). 
366

367

368

369

370

371

372

373

374

375

376

377

378

379

380

381

382

383

384

385

386

387

388

389

390

391

392

393

394

395
Figure 1

A. tsugae

A. tsugae

Sisten generation

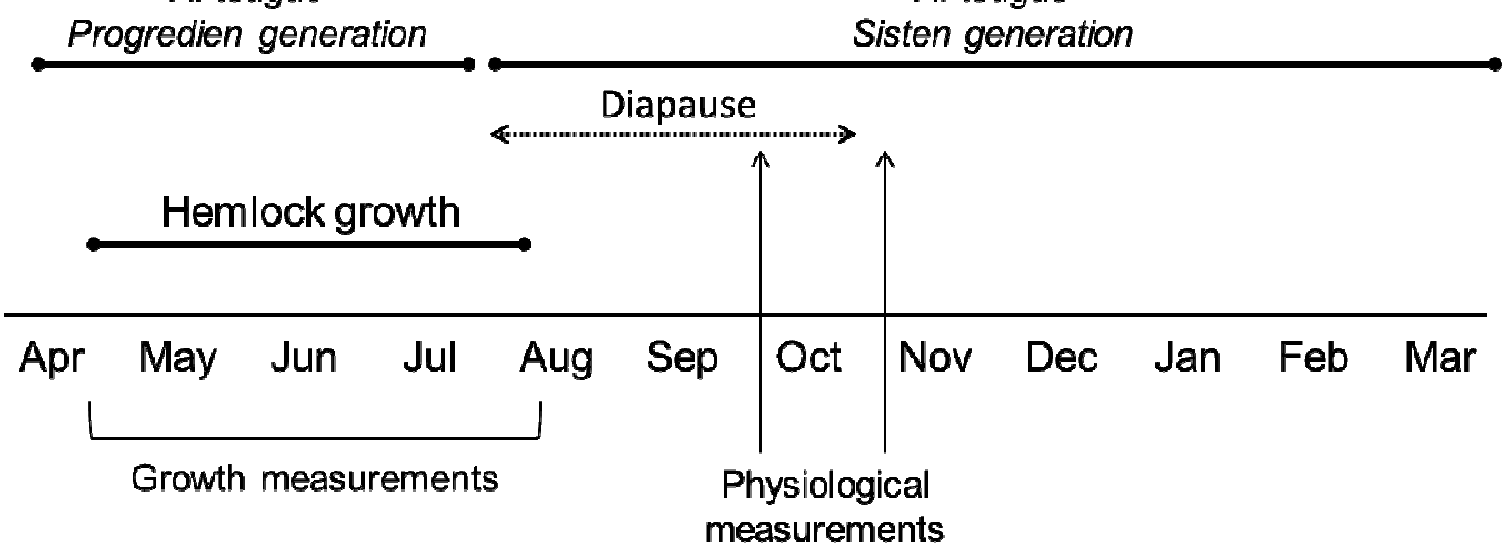


Figure 2

400

401

402

403

404

405

406

407

408

409

410

411

412

413

414

415

416

417

418

419

420
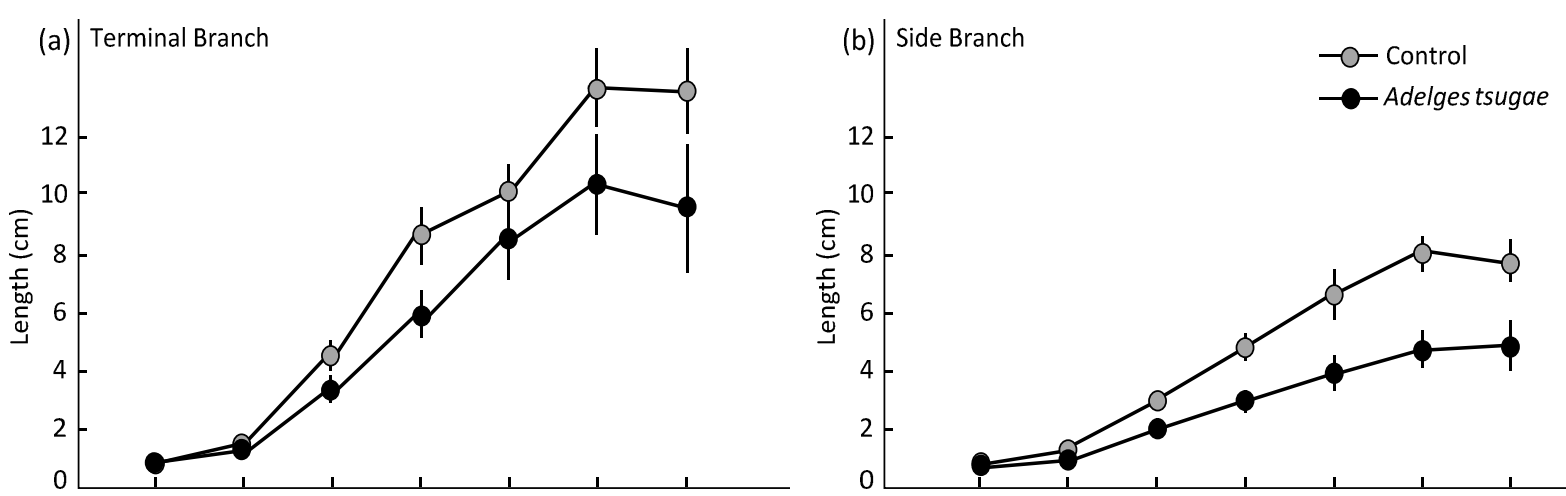

\begin{abstract}
(c) Terminal Branch
\end{abstract}
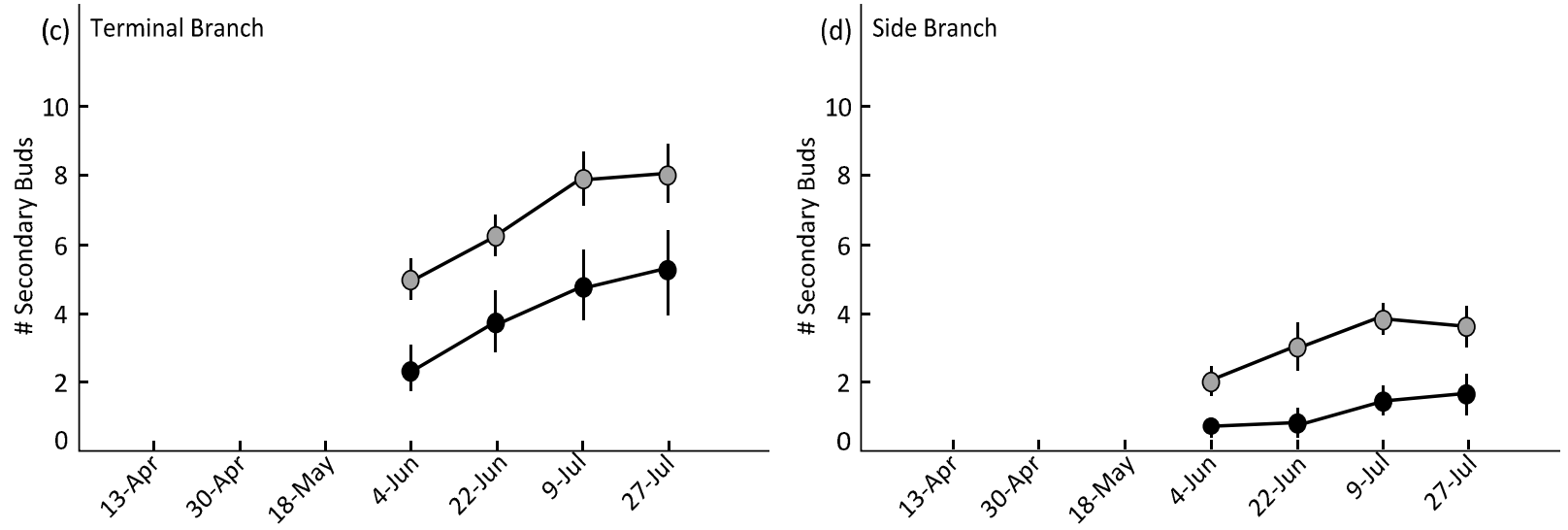
421

422

423

424

425

426
Figure 3

September

October

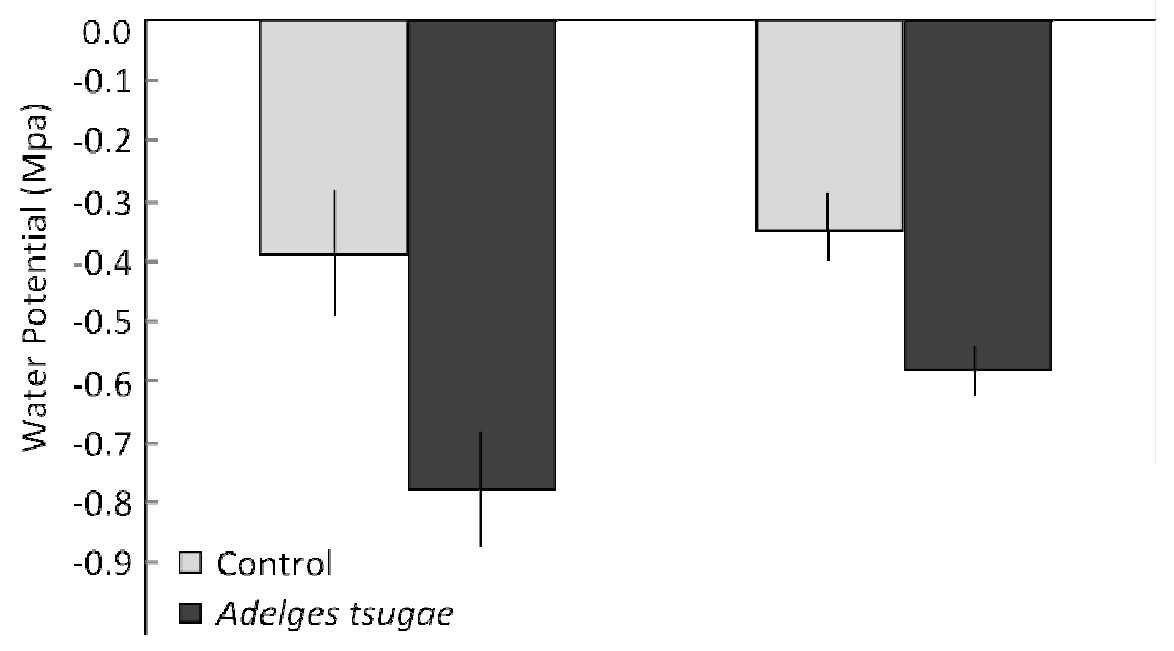


Figure 4

449

450

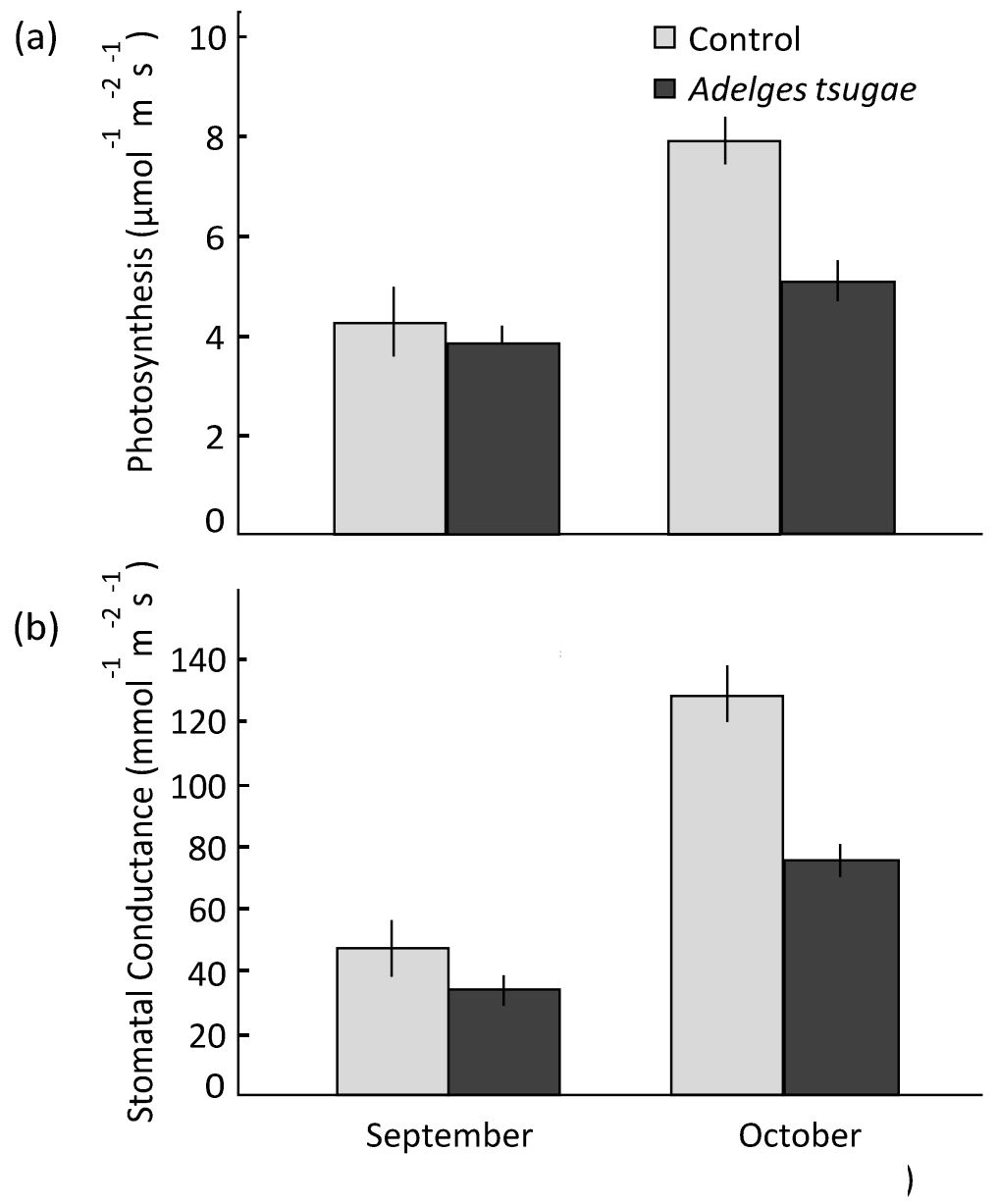


Figure 5

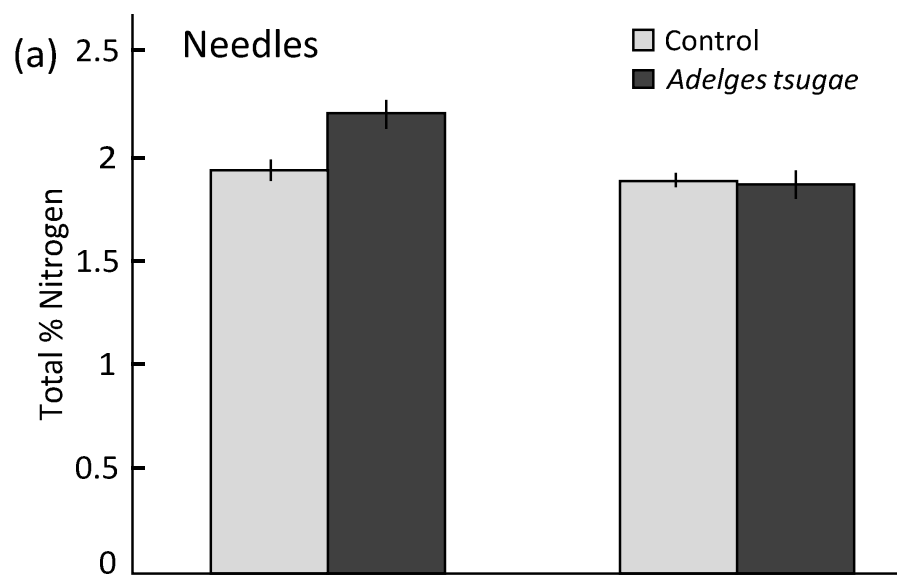

(b) 2.5

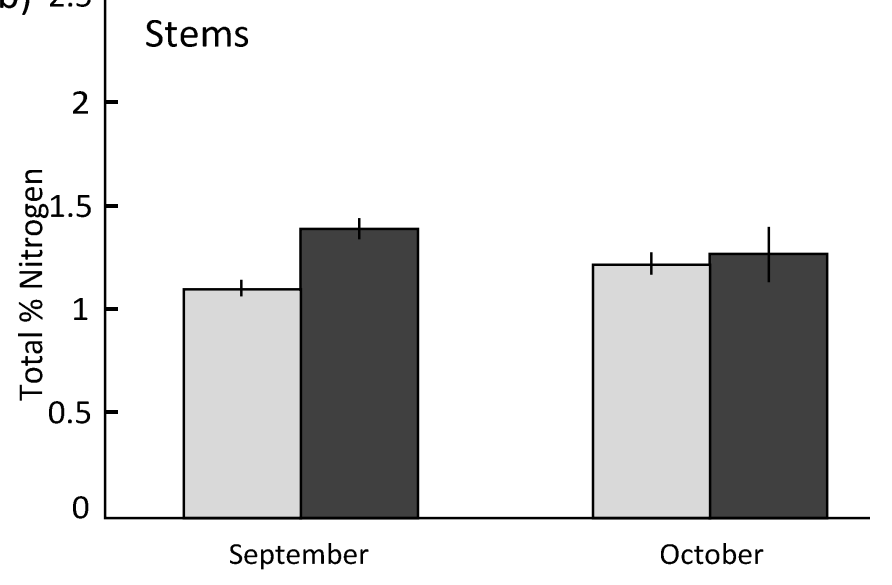

